УДК $811.161 .2 ’ 373.43(075.8)$

DOI:

Леся Заводна, методист кабінету редакиійно-видавничої діяльності

Рівненського обласного інституту післядипломної педагогічної освіти, магістр філологї̈

\title{
ЛЕКСИЧНІ НОВОТВОРИ, ВИНИКНЕННЯ ЯКИХ ЗУМОВЛЕНО СУЧАСНИМИ СУСПЛЬНИМИ ПРОЦЕСАМИ
}

Статтю присвячено дослідженню причин появи лексичних новотворів, що з'явилися у мовленні українців під впливом сучасних суспільних прочесів, а саме Євромайдану, російсько-украӥнської війни на Сході Украӥни, а також пандемії коронавірусу COVID-19. Доведено, щьо виникнення неологізмів пояснюється передусім соціальними “вибухами” та різкими змінами в сочіумі, як-от військово-політичними конфліктами, протестами, кризовими ситуачіями, суспільними негараздами, що миттєво знаходять рефлексію у мові, зокрема через неологічні утворення, які чинять відчутний вплив на суспільство.

Ключові слова: лексичні новотвори; сучасні суспільні прочеси; неологізми Євромайдану; пандемійна лексика.

Jim. 7.

Lesya Zavodna, Methodist of the Editorial and Publishing Unit, Rivne Regional Institute of Postgraduate Pedagogical Education, Master in Philology

\section{APPEARANCE OF THE LEXICAL NEOLOGISMS WHICH ARE CAUSED BYA MODERN SOCIAL PROCESS}

The article deals with the study of the causes of lexical neologisms that appeared in the speech of Ukrainians under the influence of modern social processes, namely Euromaidan, the Russian-Ukrainian war at eastern Ukraine and the COVID-19 coronavirus pandemic. The emergence of neologisms are explained primarily by social "explosions" and by abrupt changes in society such as, political conflicts, protests, crises, social unrest, which are instantly reflected in language, in particular through neologism formations that have a significant impact on society.

It is emphasized that language is considered to be the indicator of changes in society. -Economic, political, social and almost all important changes in our lives are instantly reflected in everyday vocabulary, causing the emergence of new words and new meanings. Under these circumstances, the lifespan of newly created words depends on how important social changes are.

It is substantiated that language is a complex mechanism, which is in constant motion, which ensures its viability. It is also determined that language retains the signs of immanent stability and integrity, being the main means of communication. Appearance of numerous neologisms in the modern Ukrainian language is an objective process of linguistic progress, without which it is difficult to imagine any language today.

It is proved that some concepts and terms have already ceased to be neologisms and have become part of the active vocabulary of the Ukrainian language. Others, according to the Dictionary of Modern Ukrainian Language and Slang "Myslovo", neologisms have become extremely popular in both written and oral speech of Ukrainians. In particular: "Euromaidan" (word of 2013); "Cyborgs" (2014); "Blockade" (2015); "Corruption" (2016); "Visafree" (2017); "Tomos" (2018); "Digitalization" (2019); "Coronavirus" (2020). vocabulary.

Keywords: lexical neologism; modern social processes; neologisms of the Euromaidan period; pandemic

“Нова доба нового прагне слова". Максим Рильський

$\Pi$ остановка проблеми. Найважливішою умовою існування мови єї̈ безперервний розвиток, який виражається в появі нових слів. Процес пізнання світу, зміни в суспільномужитті, прогрес у науці й техніці відбуваються безперервно, а отже, вимагають від мови забезпечення мовців необхідною кількістю нових лексичних одиниць. Тобто поява в мові низки неологізмів є об'єктивним процесом мовного прогресу, без якого важко уявити сьогодні будьяку мову, зокрема й українську.
Аналіз останніх досліджень і публікацій. Проблема лексичних новотворів та їхне функціонування в українській мові неодноразово ставало предметом аналізу багатьох ученихмовознавців. Так, це питання на різних часових зрізах досліджували І. Білодід, Г. Вокальчук, А. Грищенко, В. Горпинич, I. Ковалик, А. Коваль, О. Пономарів О. Сербенська, О. Тараненко, I. Ющук та ін. Останнім часом зацікавленість проблемою нових слів зростає, зокрема їхнє вивчення стало інтенсивнішим, про що свідчать 


\section{ЛЕКСИЧНІ НОВОТВОРИ, ВИНИКНЕННЯ ЯКИХ ЗУМОВЛЕНО СУЧАСНИМИ СУСПІЛЬНИМИПРОЦЕСАМИ}

розвідки Т. Весни та Т. Телецької, О. Дзюбіної, Ю. Звяги, Ж. Колоїз, Ю. Козлової, М. Малафей, С. Омельчук, Т. Мандич та ін. Ми також долучилися до розгляду слів-новотворів, зокрема аналізували неологізми, виникнення яких зумовлено сучасними модернізаційними процесами у вітчизняній освіті [1].

Попри значне зацікавлення з боку науковців, ці лексичні одиниці не надто активно піддаються всебічному системному лінгвістичному аналізу вчених-мовознавців, а отже, $є$ потреба у їхній грунтовній характеристиці.

Мета статті - схарактеризувати лексичні новотвори в українській мові, виникнення яких зумовлено впливом сучасних суспільних процесів.

Виклад основного матеріалу. Мова як живий та динамічний організм завжди однією 3 перших реагує на різкі зміни в соціумі. Будь-які військово-політичні конфлікти, протести, кризові ситуації, суспільні негаразди миттєво знаходять рефлексію у мові, зокрема через неологічні утворення [2].

Соціальні “вибухи” завжди чинять відчутний вплив на суспільство. Найяскравішим індикатором різноманітних змін у суспільстві (економічних, політичних, соціальних) вважається мова. Практично всі більш-менш важливі зміни в нашому житті миттєво відображаються в повсякденному словнику. Передусім - це поява нових слів і нових значень. А наскільки соціальні зрушення $\epsilon$ вагомими, залежить і тривалість життя того чи того новоствореного слова [4].

Чимала кількість неологізмів з'явилася за сучасних умов розвитку українського суспільства. Спробуємо проаналізувати найбільш знакові з них, що увійшли впродовж останніх років до розмовного словника українців, та стали своєрідним віддзеркаленням певних подій у житті держави.

Як відомо, найбільше вплинули на життя українців анексія Криму та події 2013-2014 рр., що, безперечно, відобразилося в мові й спричинило появу значної кількості новотворів, а саме:

“Анексія" (окупація АР Крим та Севастополя Росією) - збройна агресія Росії, спрямована на насильницьке протиправне відторгнення Криму та Севастополя від України та приєднання їх до РФ на правах так званих суб'єктів федерації, що було здійснено впродовж березня 2014 р.

“Кримнаш”- утворене від словосполучення “Крим наш”. Уживається з кількома значеннями: 1) назвапівострова Кримпісля окупації; 2) фанатичний прояв патріотизму, викликаний сумнівними державними здобутками.

2013 р. в Україні став роком Революції Гідності, а найпопулярнішим неологізмом - “Свромайдан”. Синонімами до нього є “Еврореволюція”, “Революція 2013 року”, “Революція Гідності”, - національно-патріотичні, протестні акції в Україні передусім проти корупції, соціальної нерівності, свавілля правоохоронних органів та сил спецпризначення, а також на підтримку європейського вектора зовнішньої політики України [5]. Слово “Свромайдан” стало словом 2013 р. за версією словника сучасної української мови та сленгу “Мислово”. Найтрагічнішим неологізмом Євромайдану, безперечно, є “Небесна сотня” - словосполучення, що використовується на позначення загиблих учасників акцій протесту в Україні в грудні 2013 - лютому 2014 років.

У період Свромайдану та Революції Гідності 3'явилися й інші новотвори, як-от:

“Timушки” - збірна назва найманих молодиків, які займаються бойовими видами спорту та мають характерний зовнішній вигляд (зазвичай одягнуті у спортивну форму та шкіряні куртки). Українська влада за часів президентства В. Януковича використовувала тітушок для участі в масових сутичках, у боротьбі з опозиційними активістами.

“Автомайдан” - мобільний підрозділ Євромайдану, що стихійно з'явився у першу добу після розгону силовиками “студентського Майдану” в ніч на 30 листопада 2013 р. Акції Автомайдану збирали сотні автомобілів, а його активісти піддавалися жорстокому переслідуванню з боку тітушок і силовиків, їхні автомобілі спалювали невідомі.

Цьогоріч минає 8 років від подій, описаних вище. Такі поняття, як “Майдан” та “Свромайдан” уже глибоко закарбувалися у свідомості українців, стали історією не лише України та Свропи, а й усього світу, увійшли до підручників історії.

2014 р. став роком війни. У лексиконі кожного українця не лише стали звичними терміни, пов'язані з війною, а й сама війна стала джерелом творення нових слів та словосполучень:

“Cenap” (cenapamucm) - житель України, який активно підтримує ідею порушення територіальної цілісності країни. "Сєпарами” зазвичай називати жителів Донбасу та Криму, які виходили на мітинги за приєднання до Росії, а пізніше приєдналися до бойовиків так званих ЛНР і ДНР.

“Ватники” (“вата”) - термін на означення представника радянської країни, який ненавидить інші народи лише за те, що вони прагнуть розвиватися, жити заможно в демократичній країні. 


\section{ЛЕКСИЧНІ НОВОТВОРИ, ВИНИКНЕННЯ ЯКИХ ЗУМОВЛЕНО СУЧАСНИМИСУСПЛЬНИМИПРОЦЕСАМИ}

“Укроп” (УКРаӥнський ОПір) - українець у російському інформаційному просторі та у свідомості частини населення Російської Федерації.

“Кіборги”- українські військові, які захищали Донецький аеропорт, прозвані так за мужність і хоробрість.

Антитерористична операція (АТО) комплекс скоординованих спеціальних заходів, спрямованих на попередження, запобігання та припинення злочинних діянь, здійснюваних із терористичною метою, звільнення заручників, знешкодження терористів, мінімізацію наслідків терористичного акту чи іншого злочину, здійснюваного з терористичною метою. Із квітня 2018-го року режим АТО офіційно змінив вивіску і перетворився на “Операцію об'єднаних сил” (OOC).

“Атошники” - так почали називати учасників бойових дій на Сході України після оголошення АТО.

“Волонтер” - людина, яка займається суспільно корисною діяльністю на добровільній та безоплатній основі. В Україні означений термін набув найбільшого поширення у період Революції Гідності та війни на Сході України.

“Доброволець”- особа, що здійснює будь-яку діяльність добровільно, часто безоплатно, не отримуючи за це матеріальної винагороди. У військовій справі (у нашому випадку - українські добровольці під час АТО) - людина, що вступила на військову службу за власним бажанням чи в діючу армію однісї з воюючих країн.

Серед неологізмів, які поповнили мовний словник українців у 2015-2017 pр. та відображали провідні події суспільно-політичного життя держави, варто виокремити такі:

“Блокада"-система заходів, які застосовуються до держави шляхом порушення її зовнішніх зв'язків, щоб примусити блоковану державу виконати певні дії або утриматись від них.

“Переселенці” (у цей період - вимушені переселенці російсько-української війни) категорія громадян України, іноземців або осіб без громадянства, котрі були змушені покинути своє місце проживання у результаті або з метою уникнення негативних наслідків збройного конфлікту на частині території Донецької і Луганської областей України або окупованого Криму.

“Поліція” (патрульна поліція) - орган державної влади (система державних органів), що займається охороною громадського порядку i боротьбою з правопорушеннями. Означений термін, хоч і був раніше відомий українцям, по- новому почав сприйматися саме із вересня 2015 р., коли на вулицях Києва та інших українських міст з'явилися поліцейські -представники Національної поліції, яка була створена за зразком “цивілізованих країн” і замінила міліцію, що дісталася нам у спадок від СРСР.

“Мурал” - різновид монументального і декоративного малярства, що виконувалося безпосередньо на стіні або на штукатурці, закріпленій на стіні, в якому фігуративні образи й декоративні орнаменти підпорядковуються архітектурним формам. Сьогодні дивовижні мурали, розміщені на будинках в усіх містах України, радують око і роблять наше життя яскравішим і прекраснішим.

“Корупція” - використання особою наданих їй службових повноважень та пов'язаних із цим можливостей із метою одержання неправомірної вигоди. На думку багатьох, саме корупція завдає країні більшої шкоди, ніж війна з Росією. У 2016 р., за версією онлайн-словника неологізмів та сленгу сучасної української мови “Мислово”, Україна була визнана найбільш корумпованою державою Європи, а згаданий вище термін-неологізм не випадково був названий словом 2016 р.

“E-декларація” - щорічна декларація, яка подається державними службовцями та іншими публічними посадовими особами та вноситься до електронного реєстру декларацій. Завдяки Едеклараціям українці отримали змогу ознайомитися із доходами високопосадовців.

“Безвізовий режим” (безвіз) - статус, що дозволяє громадянам України вільно перетинати міждержавні кордони країн Свропейського Союзу без попереднього оформлення візи (починаючи із 11 червня 2017 р). Саме “безвіз” став Словом року - 2017 [5].

“Криптовалюта” - цифрова валюта, що існує у вигляді програмних кодів. Вона може бути засобом обміну та об'єктом власності. Найдорожчою криптовалютою $є$ біткоїн.

“Cпінер” (вертун, крутилка) - антистресова іграшка із підшипником посередині й кількома лопатями по боках. У 2017 р. не лише Україна, а й увесь світ пережив справжню епідемію захоплення цією іграшкою.

“Свробляхи”- назва вживаних нерозмитнених легкових автомобілів з іноземною реєстрацією (“на єврономерах”), увезених до України без сплати мита та подальшої перереєстрації.

Упродовж 2018-2019 рр. словник українців поповнили такі лексичні новотвори:

“Toмос" - символ утворення в Україні автокефальної помісної церкви та подальшого відходу від ідеологічного впливу Москви. 


\section{ЛЕКСИЧНІ НОВОТВОРИ, ВИНИКНЕННЯ ЯКИХЗУМОВЛЕНО СУЧАСНИМИСУСПІЛЬНИМИПРОЦЕСАМИ}

Донедавна відоме лише вузькому колу посвячених у релігійну термінологію людей, у 2018 р. воно викликало найбільший суспільний інтерес, коли президент України Петро Порошенко попросив парламент підтримати його звернення до Вселенського Патріарха Варфоломія щодо надання томосу про Українську помісну автокефальну церкву. Відтоді інтерес до цього слова 3 боку українських медіа та суспільства лише зростав, а в грудні українці назвали об'єднання церкви та надання томосу головною політичною подією року. Це поняття словник “Мислово” назвав словом 2018 року.

Діджиталізація (від англ. digitalization переведення інформації в цифрову форму) - зміни в усіх сферах суспільного життя, пов'язанні 3 використанням цифрових технологій. Означене вище знайшло своє місце й у сфері державного управління, зокрема в Україні було створено Міністерство цифрової трансформації, яке має амбітні плани щодо діджиталізації держави.

Докорінно змінила життя не лише України та українців, а й усього світу пандемія коронавірусу COVID-19, що охопила світ на початку 2020 р. Bipyc, назва якого ще рік тому була відома лише вузькому колу медичних фахівців, у прямому сенсі цього слова сколихнув світ, причому зміни торкнулися і роботи та доходів, і таких речей, як спосіб життя, дозвілля і спілкування, він визначально вплинув і на мову, спричинивши появу нових слів. Тому “найактуальнішим неологічним кластером сьогодення $\epsilon$ короновірусний вокабуляр, який репрезентується словами та виразами, що виникли під впливом пандемії в період із лютого 2020 р. й до сьогодні" [2].

Уживання лексем, тематично пов'язаних зі світовою пандемією коронавірусу, є досить поширеним у лексиконі сучасних українців. Зокрема спостерігається висока частотність використання нових слів медичного спрямування і не тільки, а також слів, що набули нових значень. У зв'язку з цим, беручи за основу дослідження С. Омельчук, Т. Мандич, та доповнивши його низкою власних знахідок, виокремимо новотвори, що позначають:

- назву хвороби і пов'язані з нею новотвори: коронавірус, коронавірусна хвороба COVID19, корона, коронованиц, ковід, ковідники, ковід-дисиденти, короніали;

- назви медичних станів, процесів та конкретних предметів: карантин, пандемія, захисні маска, респіратори, ПЛР-тест, експрестест, антисептик, дезінфекція, вакциина, вакцинація, щеллення, вірус, санітайзер, пульсоксиметр, сатурація, прилад ШВЛ;
- назви соціальних явищ, викликаних пандемією: локдаун, дистанційна освіта, дистанційне навчання, дистанційка, самоізолячія, обсервація, сочіальна дистанція, ізолячія, спецрейси, специперевезення, спеиперепустки, ZOOM [6, 113].

Отже, серед низки слів та виразів, що з'явилися під впливом поширення коронавірусної хвороби, “словник епохи коронавірусу” поповниться такими найяскравішими, на нашу думку, “пандемійними новотворами”:

Локдаун - уведення суворих обмежень на виїзди, подорожі, соціальну взаємодію й доступ до громадських місць.

Карантин - обмеження в період епідемії 3 метою скорочення кількості контактів між людьми та поширення хвороби.

Пандемія - результат швидкого та неконтрольованого поширення коронавірусу, що викликав паніку в усьому світі та призвів до запровадження карантинів і локдаунів.

Самоізоляція - утримання від будь-яких безпосередніх контактів із зовнішнім світом, щоб не заразитися самому або не заразити інших.

Соціальна дистанція - комплекс санітарноепідеміологічних заходів немедикаментозного характеру, спрямованих на зупинку або уповільнення поширення коронавірусу (мінімальна відстань між людьми має складати 1,5-2 метри; відмова від рукостискань, обіймів та інших контактів тощо).

Вакцинація - уведення антигенного матеріалу $з$ метою викликати імунітет до інфекційної хвороби, який запобігає зараженню або ослаблює його негативні наслідки (на сьогодні у мовленні українців з'явилися такі нові слова, що позначають назви вакцин: пфайзер (Pfizer), коронавак (CoronaVac), астразенека (AstraZeneca), модерна (Moderna).

Дистанційне навчання (дистанційка) сукупність сучасних технологій, що забезпечують доставку інформації в інтерактивному режимі за допомогою використання інформаційнокомунікаційних технологій від тих, хто навчає (викладачів, визначних постатей у певних галузях науки, політиків), до тих, хто навчається (студентів чи слухачів).

Zoom - платформа для відеоконференцій, онлайн-зустрічей і нарад, у відеочатах якої можуть одночасно брати участь до 100 учасників; стала одним із головних засобів спілкування під час пандемії (поряд із робочими нарадами популярними стали такі терміни, як Zoomзаняття, Zоот-уроки, Zоот-вечірки, Zооткониерти) [7; 6].

Таким чином, за версією Словника сучасної 


\section{ЛЕКСИЧНІ НОВОТВОРИ, ВИНИКНЕННЯ ЯКИХ ЗУМОВЛЕНО СУЧАСНИМИСУСПЛЬНИМИПРОЦЕСАМИ}

української мови та сленгу “Мислово” [6], серед найпопулярніших лексичних новотворів останніх років стали: “Свромайдан” (слово 2013 року); “кіборги” (2014); “блокада" (2015); “корупція" (2016); “безвіз" (2017); “томос" (2018); “діджиталізація” (2019); “коронавірус” (2020).

Висновки і перспективи подальших досліджень. Отже, у динамічній системі, якою є мова, немає жодної сили, яка б гарантувала збереження регулярності, властивої тому чи тому явищу: вона є складним механізмом, який, 3 одного боку, перебуває в безперервному русі, що забезпечує його життєздатність, а 3 іншого зберігає ознаки іманентної стабільності та цілісності, будучи основним засобом комунікації. Очевидно, саме тому питання про мовну змінність, сутність $і$ чинники мовної еволюції було, $є$ і залишається одним із ключових у лінгвістичній науці [3]

Сподіваємося, що чимало новотворів, які 3'явилися у періоди соціальних “вибухів”, передусім російсько-української війни на Сході України чи пандемії коронавірусу COVID-19, незабаром вийдуть $з$ активного вжитку, хоча, на нашу думку, деякі з них усе ж стануть частиною активної лексики української мови та увійдуть до сучасних словників.

Наші подальші розвідки плануємо присвятити дослідженню авторських неологізмів сучасних письменників.

\section{ЛІТЕРАТУРА}

1. Заводна Л. Неологізми, виникнення яких зумовлено сучасними модернізаційними процесами у вітчизняній освіті. Нова педагогічна думка. 2019. № 4. C. 96-100. URL: http://npd.roippo.org.ua/index.php/ NPD/issue/view/2/3.

2. Козлова Ю. Пандемійна лексична інноватика англійської мови: особливості творення та функціонування. 2021. URL: https://science. donnu.edu.ua/ wp-content/uploads/sites/6/2021/04/korona.pdf.

3. Колоїз Ж. Українська неологія: здобутки та перспективи: матеріали Всеукр. наук. конфер. “Еволюційні тенденції в мові”. Наукові праці: науковометодичнийжурнал. Серія "Філологія. Мовознавство”. Миколаїв: Чорноморський держ. ун-т ім. П. Могили. 2009. Т. 105. Вип. 92. С. 56-61.

4. Малафей М. Лексичні новотвори як репрезентанти новітніх політичних подій (на матеріалі мовлення Євромайдану). Стиль $і$ текст: щорічний науковий збірник. Київ, 2014. Вип. 15. С. 202-210. URL: file://C:/ Users/Yaroslav4yk/Downloads/sit_2014_15_23.pdf.

5. Мислово: онлайн-словник неологізмів та сленгу сучасної української мови. URL: http://myslovo.com/.

6. Омельчук С. А., Мандич Т. М. Контекстний аналіз абревіатури Covid-19 та лексичних варіантів іiі на перетині лексикології, словотвору й синтаксису. Виклики та досягнення європейських крайн у галузі філологічних досліджень: колективна монографія.
Рига, Латвія: “Видавництво Baltija”, 2020. 626 c. URL: http://baltijapublishing.lv/omp/index.php/bp/catalog/ download/96/2418/5194-1 ?inline=1.

7. Словник епохи коронавірусу: 20 термінів, які завжди нагадуватимуть про весну 2020. BBC News. Україна. 2020. 11 квітня. URL: https://www.bbc.com/ ukrainian/features-52212810.

\section{REFERENCES}

1. Zavodna, L. (2019). Neolohizmy, vynyknennia yakykh zumovleno suchasnymy modernizatsiinymy protsesamy u vitchyznianii osviti [Neologisms, the emergence of which is caused by modern modernization processes in domestic education]. A new pedagogical idea. No. 4, pp. 96-100. Available at: http://npd.roippo.org.ua/index.php/NPD/ issue/view $/ 2 / 3$. [in Ukrainian].

2. Kozlova, Yu. (2021). Pandemiina leksychna innovatyka anhliiskoi movy: osoblyvosti tvorennia ta funktsionuvannia [Pandemic lexical innovation of the English language: features of creation and functioning]. Available at: https://science.donnu.edu.ua/wp-content/ uploads/sites/6/2021/04/korona.pdf. [in Ukrainian].

3. Koloiz, Zh. (2009). Ukrainska neolohiia: zdobutky ta perspektyvy [Ukrainian neology: achievements and prospects]. "Evoliutsiini tendentsii v movi". Materialy Vseukr. nauk. konfer.- "Evolutionary trends in language". Proceedings All-Ukrainian Science Conference. Scientific works: scientific and methodical journal. Series "Philology. Linguistics. Mykolaiv, p. 105, Vol. 92, pp. 5661. [in Ukrainian].

4. Malafei, M. (2014). Leksychni novotvory yak reprezentanty novitnikh politychnykh podii (na materiali movlennia Yevromaidanu) [Lexical innovations as representatives of modern political events (based on Euromaidan language)]. Style and text: annual scientific collection. Kyiv, Vol. 15, pp. 202-210. Available at: file:/// C:/Users/Yaroslav4yk/Downloads/sit_2014_15_23.pdf. [in Ukrainian].

5. Myslovo: onlain-slovnyk neolohizmiv ta slenhu suchasnoi ukrainskoi movy [Myslovo: online dictionary of neologisms and slang of the modern Ukrainian language]. Available at: http://myslovo.com/. [in Ukrainian].

6. Omelchuk, S. A. \& Mandych, T. M. (2020). Kontekstnyi analiz abreviatury Sovid-19 ta leksychnykh variantiv yii na peretyni leksykolohii, slovotvoru y syntaksysu [Contextual analysis of the abbreviation Covid19 and its lexical variants at the intersection of lexicology, word formation and syntax]. Challenges and achievements of European countries in the field of philological research: a collective monograph. Ryha, Latviia, $626 \mathrm{p}$. Available at: http://baltijapublishing.lv/omp/index.php/bp/catalog/ download/96/2418/5194-1?inline=1. [in Ukrainian].

7. Slovnyk epokhy koronavirusu: 20 terminiv, yaki zavzhdy nahaduvatymut pro vesnu 2020 [Dictionary of the coronavirus era: 20 terms that will always be reminiscent of spring 2020]. (2020). BBC News. Ukraina. Available at: https://www.bbc.com/ukrainian/features52212810. [in Ukrainian].

Стаття надійшла до редакції 14.09.2021 